\title{
Sonometri fetus kambing kacang usia 7 minggu hasil superovulasi menggunakan hormon PMSG
}

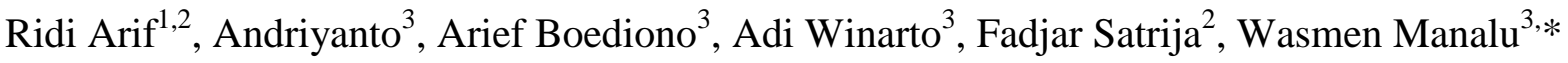 \\ ${ }^{1}$ Program Doktoral, Sekolah Pascasarjana, Institut Pertanian Bogor, Bogor \\ ${ }^{2}$ Departemen Ilmu Penyakit Hewan dan Kesehatan Masyarakat Veteriner, Fakultas Kedokteran Hewan, \\ Institut Pertanian Bogor, Bogor \\ ${ }^{3}$ Departemen Anatomi Fisiologi dan Farmakologi, Fakultas Kedokteran Hewan, Institut Pertanian Bogor, Bogor
}

\begin{abstract}
ABSTRAK: Teknologi superovulasi dapat dimanfaatkan untuk meningkatkan sekresi endogen hormon kebuntingan. Salah satu manfaat dari peningkatan sekresi endogen hormon kebuntingan adalah perbaikan perkembangan lingkungan uterus selama kebuntingan. Kambing Kacang betina sebanyak 8 ekor dan telah dewasa kelamin dengan bobot rataan $22 \mathrm{~kg}$ dibagi ke dalam dua kelompok yaitu kelompok kontrol (tidak disuperovulasi) dan kelompok superovulasi menggunakan hormon Pregnant Mare Serum Gonadotropin (PMSG) dengan dosis $15 \mathrm{IU} / \mathrm{kgBB}$. Kambing Kacang percobaan diserentakkan berahinya menggunakan $\mathrm{PGF}_{2 \alpha}$ sebanyak 2 kali dengan selang 11 hari. Penyuntikan PMSG dilakukan bersamaan dengan penyuntikan $\mathrm{PGF}_{2 \alpha}$ kedua pada kelompok superovulasi. Setelah berahi, semua kambing dikawinkan secara alami dengan pejantan pilihan. Fetus kemudian diukur secara ultrasonografi (USG) pada usia kebuntingan 7 minggu. Hasil pengukuran menunjukkan kelompok Kambing Kacang hasil superovulasi memiliki ukuran fetus yang lebih panjang daripada kelompok kontrol $(\mathrm{P}<0.05)$. Ukuran diameter amnion terpanjang dan terpendek serta tebal dinding uterus terlihat cenderung meningkat pada kelompok superovulasi dibandingkan dengan kelompok kontrol $(\mathrm{P}>0.05)$. Kesimpulan penelitian ini adalah superovulasi pada induk Kambing Kacang mampu meningkatkan pertumbuhan fetus sampai dengan usia kebuntingan 7 minggu.
\end{abstract}

Keywords:

superovulasi, PMSG, fetus, kebuntingan 7 minggu, Kambing Kacang

\section{- PENDAHULUAN}

Pemanfaatan teknologi superovulasi saat ini tidak hanya terbatas pada kepentingan embrio transfer. Salah satu manfaat lain superovulasi adalah efek stimulasi ovarium berupa peningkatan sekresi endogen hormon kebuntingan. Superovulasi pada Kambing Kacang memberikan pengaruh berupa peningkatan jumlah dan ukuran folikel dominan serta korpus luteum yang terbentuk yang pada akhirnya meningkatkan konsentrasi serum progesteron dan esterogen induk (Andriyanto et al. 2017).

Induk kambing yang disuperovulasi memiliki produksi susu lebih optimum sehingga dapat menunjang kehidupan anaknya (Manalu et al. 2000). Anak yang dihasilkan dari induk yang disuperovulasi juga memiliki bobot lahir yang lebih besar, tingkat kematian yang lebih rendah, dan bobot sapih yang lebih besar (Manalu dan Sumaryadi 1998).

Secara umum, produktivitas anak kambing hasil induk superovulasi lebih baik dibandingkan dengan anak kambing dari induk yang tidak disuperovulasi (Andriyanto dan Manalu 2011). Namun, data produktivitas anak dari induk yang disuperovulasi merupakan data anak setelah lahir sedangkan perkembangan selama dalam kandungan belum pernah diamati. Oleh karena itu penelitian ini bertujuan untuk mengamati perkembangan fetus dalam kandungan induk yang disuperovulasi pada usia kebuntingan 7 minggu.

\section{- BAHAN DAN METODE}

Kambing Kacang sebanyak 8 ekor betina dewasa kelamin dengan bobot rata-rata $22 \mathrm{~kg}$ dibagi ke dalam dua kelompok perlakuan yaitu kelompok kontrol (tidak disuperovulasi) dan kelompok superovulasi. Penyerentakkan berahi dilakukan dengan menyuntikkan hormon $\mathrm{PGF}_{2 \alpha}$ sebanyak dua kali dengan selang 11 hari. Perlakuan superovulasi dilakukan dengan menyuntikkan hormon Pregnant Mare Serum Gonadotropin (PMSG) dosis $15 \quad \mathrm{IU} / \mathrm{KgBB}$ bersamaan dengan penyuntikkan $\mathrm{PGF}_{2 \alpha}$ yang kedua. Sehari setelah penyuntikkan $\mathrm{PGF}_{2 \alpha}$ yang kedua, kambing menunjukkan gejala berahi dan kemudian dikawinkan. Fetus pada usia kebuntingan 7 minggu dilakukan pemeriksaan secara ultrasonografi (USG) (Aloka SSD-500, Japan), linear probe, $7.5 \mathrm{MHz}$. Parameter yang diukur adalah diameter amnion (terpanjang dan terpendek), dinding

Diterima: 11-01-2018 | Direvisi: 26-01-2018 | Disetujui: 29-01-2018 (C) 2018 CC-BY-SA. Ini adalah artikel Open Access yang didistribusikan berdasarkan ketentuan dari Creative Commons Attribution ShareAlike 4.0 International License (https://creativecommons.org/licenses/by-sa/4.0/). 
uterus, dan panjang fetus dengan titik orientasi dari ujung kepala ditambah panjang vertebrae (Gonzales-Bulnes et al. 2010). Hasil pengukuran fetus kemudian dianalisis dan dibandingkan diantara kelompok dengan uji independent $T$ Test menggunakan perangkat lunak SPSS 16.

\section{- HASIL DAN PEMBAHASAN}

Hasil pengamatan USG pada usia kebuntingan 7 minggu disajikan pada Gambar 1. Citra sonogram fetus menunjukkan ukuran kepala yang lebih besar dan vertebrae yang lebih panjang pada fetus dari induk yang disuperovuasi. Ukuran diameter amnion tidak terlalu berbeda antara kelompok kontrol dengan superovulasi.

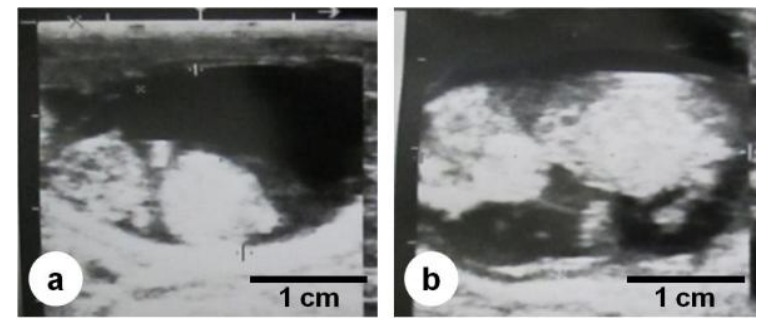

Gambar 1. Hasil pemeriksaan USG fetus pada induk Kambing

Kacang usia kebuntingan 7 minggu pada kelompok kontrol (a) dan superovulasi (b).

Hasil pengukuran fetus dalam pemeriksaan USG menunjukkan induk yang disuperovulasi memiliki ukuran fetus yaitu panjang kepala dan panjang vertebrae yang lebih tinggi dibandingkan kontrol (Tabel 1).

Tabel 1 Hasil pengukuran panjang fetus, diameter amnion, dan tebal dinding uterus.

\begin{tabular}{|l|c|c|}
\hline \multirow{2}{*}{ Variabel } & \multicolumn{2}{c|}{ Kelompok } \\
\cline { 2 - 3 } & Kontrol & Superovulasi \\
\hline Bobot induk (kg) & $22.20 \pm 4.50^{\mathrm{a}}$ & $22.85 \pm 1.11^{\mathrm{a}}$ \\
Panjang fetus (cm) & $1.97 \pm 0.32^{\mathrm{b}}$ & $2.57 \pm 0.43^{\mathrm{a}}$ \\
Diameter amnion & $3.98 \pm 0.72^{\mathrm{a}}$ & $4.13 \pm 0.69^{\mathrm{a}}$ \\
terpanjang (cm) & & \\
Diameter amnion & $2.79 \pm 0.53^{\mathrm{a}}$ & $3.13 \pm 0.28^{\mathrm{a}}$ \\
terpendek (cm) & $0.90 \pm 0.19^{\mathrm{a}}$ & $0.99 \pm 0.25^{\mathrm{a}}$ \\
\hline
\end{tabular}

Keterangan: Huruf superscript $\left({ }^{\mathrm{a}, \mathrm{b}}\right)$ berbeda pada baris yang sama menunjukkan nilai berbeda nyata $(\mathrm{P}<0.05)$.

Hasil pemeriksaan USG menunjukkan bahwa fetus dari induk yang disuperovulasi memiliki ukuran lebih panjang secara signifikan berbeda dengan kontrol. Hal ini membuktikan bahwa peningkatan sekresi endogen hormon kebuntingan melalui proses superovulasi telah memperbaiki perkembangan fetus sejak periode awal kebuntingan.

Hormon kebuntingan paling utama adalah progesteron dan esterogen (Jansson dan Powell 2007) serta yang lainnya seperti insulin, insuline like growth factor, dan tiroid (Fowden 2003; Sferruzzi-Perri et al. 2013). Superovulasi meningkatkan sekresi endogen hormon-hormon tersebut. Hormon progesteron secara spesifik meningkatkan aktivitas sel glandular dan luminal epithelial uterus sehingga lebih banyak mensekresikan uterine luminal fluid yang sangat diperlukan bagi perkembangan fetus (Cooke et al. 2013). Selain itu, peningkatan hormon kebuntingan juga meningkatkan vaskularisasi pembuluh darah pada uterus dan plasenta sehingga transportasi nutrisi dan oksigen lebih optimal (Bazer et al. 2012). Hal tersebut mendukung fetus pada kelompok superovulasi dapat tumbuh lebih cepat sehingga memiliki ukuran yang lebih besar.

\section{SIMPULAN}

Superovulasi dengan hormon PMSG pada Kambing Kacang meningkatkan sekresi endogen hormon kebuntingan yang selanjutnya meningkatkan kualitas uterus dan plasenta sehingga perkembangan fetus menjadi lebih baik.

\section{- INFORMASI PENULIS}

\section{Penulis untuk Korespondensi}

*WM: wasmenmanalu@ymail.com.

Departemen Anatomi Fisiologi dan Farmakologi,

Fakultas Kedokteran Hewan, Institut Pertanian Bogor

Jalan Agatis Kampus IPB Dramaga 16680, Bogor

\section{UCAPAN TERIMAKASIH}

Direktorat Penelitian dan Pengabdian Kepada Masyarakat, Direktorat Jenderal Pendidikan Tinggi, Kementerian Pendidikan dan Kebudayaan (Program Pengembangan IPTEKS dan PMDSU).

\section{- PUSTAKA ACUAN}

Andriyanto, Manalu W. 2011. Increased goat productivity through the improvement of endogenous secretion of pregnant hormones by using follicle stimulating hormone. Anim Prod. $9(2): 89-93$.

Andriyanto, Amrozi, Rahminiwati M, Boediono A, Manalu W. 2017. Optimum dose and time of pregnant mare serum gonadotropin injections in Kacang goats to increase endogenous secretion of estrogen and progesterone without superovulation response. Small Rumin Res. 149:147-153.

Bazer FW, Song G, Kim J, Dunlap KA, Satterfield MC, Johnson GA, Burghardt RC, Wu G. 2012. Uterine biology in pigs and sheep. J Anim Sci Biotechnol. 3(1):23.

Cooke PS, Spencer TE, Bartol FF, Hayashi K. 2013. Uterine glands: development, function and experimental model systems. Mol Hum Reprod. 19:547-558.

Fowden AL. 2003. The insulin-like growth factors and fetoplacental growth. Placenta. (8-9):803-812.

Gonzalez-Bulnes A, Pallares P, Vazquez MI. 2010. Ultrasonographic imaging in small ruminant reproduction. Reprod Domest Anim. 45:9-20.

Jansson T, Powell TL. 2007. Role of the placenta in fetal programming: underlying mechanisms and potential interventional approaches. Clin Sci (Lond). 113(1):1-13.

Manalu W, Sumaryadi MY. 1998. Maternal serum progesterone concentration during pregnancy and lamb birth weight at parturition in Javanese Thin-Tail ewes with different litter sizes. Small Rumin Res. 30:163-169.

Manalu W, Sumaryadi MY, Sudjatmogo, Satyaningtijas AS. 2000. Effect of superovulation prior to mating on milk production performances during lactation in ewes. J Dairy Sci. 83: 477483.

Sferruzzi-Perri AN, Vaughan OR, Forhead AJ, Fowden AL. 2013. Hormonal and nutritional drivers of intrauterine growth. Curr Opin Clin Nutr Metab Care. 16(3):298-309. 